\title{
Negotiating Gendered Leadership Positions within African Initiated Christian Churches in Amsterdam
}

\author{
Justice R.K.O. Kyei, Elizabeth N.M.K. Yalley, and \\ Emmanuel K.E. Antwi ${ }^{1}$
}

\author{
${ }^{1}$ SHORT BIOS \\ Justice and Elizabeth are lecturers in \\ the Department of Sociology and \\ Social Work, while Emmanuel is a \\ senior lecturer in the Department of \\ Religious Studies.
}

\section{INSTITUTIONAL AFFILIATION}

Kwame Nkrumah University of Science and Technology, Kuams

\section{ORCID}

https://orcid.org/0000-0002-3930-2239 https://orcid.org/0000-0003-0542-6492 https://orcid.org/0000-0002-6354-3606

\begin{abstract}
Our research contributes to the discussion of feminist theorists on how the dominance of women in religious communities is not reflected in leadership positions of women. With the case of African Initiated Christian Churches (AICCs) in Amsterdam, this study investigates the intersection of gender, citizenship, and religion. The concept of religious citizenship provides the analytical tool to examine women-men relationships within immigrant religious communities. The research focuses on gendered leadership within the AICCs in Amsterdam, to enquire into how women exercise leadership in spite of the challenges faced in the AICCs. Data are drawn from in-depth interviews, participant observation, and informal interviews in Amsterdam. This study concludes that women's access to hierarchical positions is nuanced, as mainline Protestant churches are more flexible compared to Pentecostal/Charis matic churches. We argue that some women are situated in de facto secondclass religious citizenship positions in religious communities which undermine women's search for equal opportunities as religious citizens. Some women, however, exercise agency to circumvent the structural constraints.
\end{abstract}

\section{KEYWORDS}

gender; religious citizenship; African Initiated Christian Churches; agency; women leadership; Ghanaian immigrants

\section{Introduction}

Feminist theorists have established that the dominant societal order is not gender neutral, but rather a masculine ethos that structurally favours men. ${ }^{1}$ In recent years, feminists have been agitating for equal rights with an inclusion and opportunities for women in the nation-state ${ }^{2}$ because women have not always been admitted as fully-fledged citizens within political communities. Feminist theorists are engendering citizenship, as membership in communities are not limited to the nation-state at the macro level, ${ }^{3}$ but includes membership also at the meso level ${ }^{4}-$ at both

1 Baukje Prins, "Mothers and Muslima's, Sisters and Sojourners: The Contested Boundaries of Feminist Citizenship," in Handbook of Gender and Women's Studies, eds. Kathy Davis, Mary Evans, and Judith Lorber (London, Sage, 2006), 237.

2 Kathy Davis, Mary Evans, and Judith Lorber (eds.), Handbook of Gender and Women's Studies (London: Sage, 2006).

3 Ruth Lister, "Citizenship and Gender," in Blackwell Companion to Political Sociology, eds. Kate Nash and Alan Scott (Oxford: Blackwell Publishing, 1997), 323. 
religious and ethnic communities. This research focuses on how belonging and leadership positions in the religious community of African Initiated Christian Churches (AICCs) are gendered.

Women's quests for liberation have revealed that religion is one of the core institutions that denigrate and marginalise women from the exercise of power and autonomy. ${ }^{5}$ Interestingly, Oduyoye notes that "God is male does not make the male God." 6 African women theologians have argued that they do want to be active participants in the religious field as healers rather than simply being healed." The study aims at contributing to the discussion on how gender matters and shapes the pattern of the social life of women in the AICCs in Amsterdam. Arguably, the study of gendered citizenship in the AICCs creates an awareness that may generate radical transformation in the status quo. Studies have examined the oppression of women in AICCs which centred mainly on the differentiation in the treatment of women and men in addressing pregnancy out of wedlock, sexuality education, and gendered sanctions of second-generation migrants in AICCs. ${ }^{8}$ Ndeda $^{9}$ also discusses the gender dynamics in leadership roles in an African Independent Church. In the study of women pastors in the Presbyterian Church of Ghana, Adasi and Frempong ${ }^{10}$ have discovered socio-cultural setbacks in their line of duty. Although Adams ${ }^{11}$ and Soothill ${ }^{12}$ have identified, to some extent, the

4 Evangelia Tastsoglou and Alexandra Dobrowolsky (eds.), Women, Migration, and Citizenship: Making Local, National, and Transnational Connections, Vol. 8 (Hampshire: Ashgate Publishing. 2006), 10.

5 Mercy A. Oduyoye, Gender and Theology in Africa Today (Accra: Institute of Women in Religion \& Culture Accra, Ghana, 2006), 4

6 Oduyoye, Gender and Theology in Africa Today, 5.

7 Mercy A. Oduyoye, Women and Ritual in Africa, in The Will to Arise: Women, Tradition, and the Church in Africa, edited by Mercy A. Oduyoye and Kanyoro R.A. Musimbi (Maryknoll: Orbis Books, 1992), 17-8.

8 Justice R.K.O. Kyei and Rafal Smocynski, "Religious citizenship and gendered sanctions in the lived experience of second generation Ghanaians," Social Compass 66, no.4 (2019): 502-21.

9 Milfred A.J. Ndeda, "The Nomiya Luo Church: A gender analysis of the dynamics of an African Independent Church among the Luo of Siaya District," in Gender, Literature and Religion in Africa, edited by Elizabeth le Roux, Mildred A.J. Ndeda, George Nyamndi, F.E.M.K. Senkoro, and Isaac Ssetuba (Dakar: Council for the Development of Social Science Research in Africa, 2005), 49-78.

10 Grace S. Adasi and Dorothy A. Frempong, "Multiple roles of African women leaders and their challenges: The case of the Presbyterian Church of Ghana," Research on Humanities and Social Sciences. 4, no.11 (2014), 63-8.

11 Carole E, Adams, Women Clerks in Wilhelmine Germany: Issues of class and gender (Cambridge: Cambridge University Press, 2002). 
leadership roles of women in Pentecostal/Charismatic churches, they conclude with caveats of their generalisation. Kapinde and Higgs also discuss how women ordination in the Anglican Church in Kenya took shape and the obstacles which they encountered in the process. ${ }^{13}$

The uniqueness of this article dwells in how it intersects gender, citizenship, and religion in understanding an equal access to hierarchical positions among immigrant religious institutions. We provide empirical evidence to demonstrate how the gendering of the concept of citizenship facilitates the discussion of the inconsistencies within the AICCs in addressing gendered aspects of leadership. The study enquires how leadership positions within the AICCs in Amsterdam are gendered, and examines how women exercise leadership in spite of the social challenges faced in AICCs. The article proceeds with the conceptualisation of gender, religious citizenship, and agency. It further briefly describes the emergence of AICCs in the Netherlands and Ghanaian population in the Netherlands, as most of the members of the AICCs studied, are Ghanaians. The study then presents the data and methods of the research and continues to elaborate on the findings and discussions. It ends with the conclusions.

\section{Conceptualising Gender, Religious Citizenship, and Agency}

In this work, gender is considered as a theoretical tool that guides the understanding of the categories of women or men in social interaction, not limited to the individual, but inclusive of social institutions like education, religion, and family ${ }^{14}$ which are also gendered. The gender category is enacted in multi-layered forms in social life that gives meaning to and shapes the pattern of social relations. Gender is both static and variable, inasmuch as it is produced and reproduced. The sociology of gender has identified social relations of domination of masculinity over femininity, which is culturally exalted. ${ }^{15}$ Gender is a system

12 Jane Soothill, "Gender and Pentecostalism in Africa," in Pentecostalism in Africa, eds. Andrew Davies and William Kay (Brill: London, 2015), 191-219.

13 Stephen A. Kapinde and Eleanor T. Higgs, "Global Anglican Discourse and Women's Ordination in Kenya: The Controversy in Kirinyaga, 1979-1992, and its Legacy," Journal of Anglican Studies (2021): 1-18.

14 Ronald Jepperson, "Institutions, Institutional Effects, and Institutionalism," in The New Institutionalism in Organizational Analysis, eds. Walter W. Powell and Paul J. DiMaggio (Chicago: University of Chicago Press, 1991), 145.

15 Robert W. Connell, Masculinities (Berkeley: University of California Press, 2005), 22. 
of social practices that constitutes people as different and that organises relations of inequality. ${ }^{16}$ Gender is conceptualised here as the "patriarchal phenomenon that structures relationships in hierarchies and pyramids."17 Oduyoye holds that gender is not limited to biological sex as it embraces power relations between men and women.

In order to facilitate the gender discussion on participation and representation in AICCs, the study employs the concept of citizenship from a feminist perspective. Traditionally the notion of citizenship has been limited to the legal political rights within the public sphere of the nationstate. ${ }^{18}$ Marshall defines citizenship as "a status bestowed on those who are full members of a community. All who possess the status are equal with respect to the rights and duties with which the status is endowed." 19 Feminist theorists have, however, argued that the plurality of communities and the varied forms of belonging result in multiple meanings and practices of membership which are not embraced in the traditional nation-state association with citizenship. ${ }^{20}$ Citizenship should therefore not be perceived as a static attribute of a group of people within a given polity. Citizenship is rather contested, fluid, and dynamic, and it involves processes of negotiation and struggle. Citizenship is therefore extended to membership at the meso and micro levels. We conceptualise citizenship not exclusively as membership in a state, but as membership in a community with the rights to participation and representation.

Drawing from the work of Kyei and Smoczynski, ${ }^{21}$ we define religious citizenship as the process of exercising equal rights to participation, representation, and identity formation by members within a religious community. Participation is conceptualised as the right to equal access by both women and men in a given religious community to partake in all forms of its activities. The rite of initiation, such as baptism, provides full

16 S. Army Wharton, The Sociology of Gender: An Introduction to Theory and Research (Oxford: Blackwell Publishing, 2005), 31.

17 Oduyoye, Gender and Theology in Africa Today, 3.

18 Bryan S. Turner, "Outline of a theory of citizenship," Sociology 24, no.2 (1990): 189217.

19 Thomas H. Marshall, Citizenship and Social Class and Other Essays (Cambridge: Cambridge University Press, 1950), 28-9; Barbara Hobson and Ruth Lister, "Citizenship," in Contested Concepts in Gender and Social Politics, eds. Barbara Hobson, Jane Lewis, and Birte Siim (Aldershut: Edward Elgar Publishing, 2002), 23-53.

20 Ruth Lister, "Citizenship: Towards a feminist synthesis," Feminist Review 57, no.1 (1997): 28-48.

21 Kyei and Smocynski, "Religious citizenship and gendered sanctions," 508. 
access to membership in a religious community. The indicators of participation are the right to vote and to access religious activities. Representation is referred to as equal rights for women and men to be elected or nominated to formal leadership positions within a religious community. The indicators of representation are nomination or election into a leadership position. The formally nominated positions in AICCs are deaconesses or deacons, elders, presiding elders, care-takers, catechists, pastors, and apostles. Women and men compete for representation within the religious field as they have the ambition to achieve full religious citizenship. The dominance of men in religious positions has embedded the competition in the religious field with a male hegemony.

In addressing the gender relations in AICCs, some women do exercise agency, trying to assume leadership positions. We argue that social actors are not completely autonomous in their engagement as they are entangled with social structures. Agency is not always explicitly contesting social structures. It rather plays according to the rules of the game to achieve the desired leadership positions, even if informally. Aymer notes how Nigerian women missionaries established para-church organisations that entrusted leadership positions to women without threatening the male hegemony in the religious field. ${ }^{22}$ Women exercise agency, but they do so within the confines of the dominant culture of the religious community. Agency for women in religious communities is about being "conscious actors, not passive subjects in the various situations in which they find themselves." ${ }^{23}$ Women position themselves as social actors with self-recognition that translates into social acknowledgement. ${ }^{24}$ Agency is thus the ability to take action in situations in which one is entangled with social structures, and that action transforms social relations in one way or the other. ${ }^{25}$

22 Paula Aymer, "West African and Caribbean women evangelists," in Spirit on the Move: Black Women and Pentecostalism in Africa and the Diaspora, eds. Judith Casselberry and Elizabeth A. Pritchard (Durham: Duke University Press, 2019), 110.

23 Helen Ralston, "Citizenship, identity, agency and resistance among Canadian and Australian women of South Asia," in Women, Migration and Citizenship: Making Local, National and Transnational Connections, eds. Evangelia Tastsoglou and Dobrowolsky (Aldershot: Ashgate Press, 2006), 184.

24 Charles Taylor, "The politics of recognition," in Multiculturalism: Examining the Politics of Recognition, ed. Amy Gutmann (Princeton, NJ: Princeton University Press, 1994), 27.

25 William H. Jr. Sewell, "A theory of structure: Duality, agency, and transformation," American Journal of Sociology 98, no.1 (1992): 20. 


\section{Emergence of AICCs in the Netherlands}

When African immigrants arrived in the Netherlands in masses during the late 1980s and early 1990s, the Catholic Church and other mainline Protestant missionary churches in the country did not immediately reach out to the pastoral needs of the immigrants. ${ }^{26}$ However, the Pentecostal/ Charismatic churches quickly started to establish their branches here and simultaneously some immigrants established new churches ${ }^{27}$ to deal with the trauma and challenges of the new environment. Most of the African-led churches that were established during the 1990s, were initiated by Ghanaians. ${ }^{28}$ There were initially 17 AICCs, and by 1997 , the number had already risen to 40 in Amsterdam alone. AICCs in Amsterdam had grown to about 150 in $2013 .{ }^{29}$ The presence of immigrant Christian churches in the host country provided an avenue for new arrivals to meet people with similar languages and worldviews. AICCs in Amsterdam provided the opportunity for some first-generation African migrants to meet and share their experiences, with the aim of helping to shed the stress and trauma that their migration trajectories might have generated. Some AICCs in Amsterdam therefore tried to provide psychosocial wellbeing services to the first-generation African immigrants.

In this research, "AICC" is defined as any Christian denomination that was initiated or newly formed in or transplanted in the host country by immigrants of African descent. The research identified two main types of AICCs in Amsterdam. Similar divisions are also noted in the study of African Christian churches in Canada. ${ }^{30}$ The first group consisted of traditional missionary churches like the Catholic, Methodist, and Presbyterian churches. The second category consisted of those churches that were Pentecostal/Charismatic in nature and were initiated by Africans rather than foreign missionaries. ${ }^{31}$

26 Chandersen E.S. Choenni, Ghanazen in Nederland. Een Profiel (Den Haag: Ministerie van Binnenlandse Zaken en Koninkrijkszaken, 2002), 24

27 Gerrie Ter Haar. "Strangers in the Promised Land: African Christians in Europe," Exchange 24, no.1 (1995): 15.

28 Ter Haar, "Strangers in the Promised Land."

29 Dick van den Bos, "Kerken in de Bijlmer zijn parels in Amsterdam-Zuidoost," Reformatorish Dagblad, 27 June 2013.

30 Joseph Mensah, "'Doing religion' overseas: The characteristics and functions of Ghanaian immigrant Churches in Toronto, Canada," Societies Without Borders 4 (2009): 21-44.

31 Kwabena J. Asamoah-Gyadu, "Mediating spiritual power: African Christianity, transnationalism and the media," in Religion crossing boundaries: Transnational religious 


\section{Ghanaians in the Netherlands}

Mass immigration of Ghanaians to the Netherlands is a relatively new phenomenon compared to the massive number of Turkish, Moroccans, Antilleans, and Surinamese immigrants who entered the country from the late 1960s onwards. However, the number of Ghanaians has grown steadily in the last three decades. ${ }^{32}$ According to the Amsterdam Bureau for Research and Statistics, Ghanaians in the Netherlands numbered about 12,480 in 1996, while in 2014, the total Ghanaian population had increased to $24,460^{33}$ out of which 10,120 belonged to the category of second generation. More than half of the Ghanaians live in Amsterdam, being the fifth largest immigrant group in this city after the Moroccans, Turkish, Antilleans, and Surinamese. ${ }^{34}$

Most Ghanaian immigrants settled in the Bijlmer district of Amsterdam and, to a lesser extent, in The Hague. ${ }^{35}$ Ghanaians in Amsterdam became well known in the Netherlands after a plane crashed into buildings in the southeast of Amsterdam in September 1992, claiming many Ghanaian lives and injuring others. ${ }^{36}$ Ghanaians in the Netherlands are from different ethnic groups in Ghana, but most of them are Akan, consisting of the Asante, Kwahu, and the Fante. Ghanaians are visible in the Netherlands through their churches, shops (food, clothing), media (television and radio broadcasting), and magazines. ${ }^{37}$ In spite of the medium education level of Ghanaians in the Netherlands, they are employed in jobs that require specific skills which are usually undervalued and feminised. The workers in these jobs are underpaid and stigmatised, mainly due to low proficiency in the Dutch language and

and social dynamics in Africa and the new African Diaspora, eds. Afe Adogame and James V. Spickard (Leiden: Brill, 2010), 87-103.

32 Statistics Netherlands, "Population: Sex, age, migration background and generation," 1 January 2019, https://opendata.cbs.nl/\#/CBS/en/dataset/37325eng/table.

33 Statistics Netherlands, "Population."

34 Gemeente Amsterdam, Amsterdam in Cifers 2013. Gemeente Amsterdam, Amsterdam: O+S Research, http://www.ois.amsterdam.nl/media/Amsterdam\%20in\%20cijfers $\% 202013 / \mathrm{HTML} / \# / 62 /$.

35 Gerrie ter Haar, "The African Diaspora in the Netherlands," in New Trends and Developments in African Religions, ed. Peter B. Clarke (Westport: Greenwood Press, 1998), 248.

36 Jeroen W. Knipscheer, Eleonore de Jong, Rolf Kleber, and Ekow Lamptey, "Ghanaian migrants in the Netherlands: General health, acculturative stress and utilization of mental health care," Journal of Community Psychology 28, no.4 (2000): 461.

37 Choenni, Ghanazen in Nederland, 24. 
discrimination in the Dutch labour market, ${ }^{38}$ as well as the cumbersome process of foreign diplomatic recognition by the Dutch government.

\section{Data and Method}

The data for this research are drawn from a research project that was conducted in Amsterdam between January 2014 and January 2015. Ethical clearance was obtained from the Ethics Committee in the Institute of Philosophy and Sociology of the Polish Academy of Sciences. Follow-up interviews were made in December 2017. The data were collected through in-depth interviews, participant observations, and informal interviews. Life history interviews were conducted with 50 AICC members in Amsterdam, out of which 35 were women and 15 were men, being representatives of nine AICCs in Amsterdam. The study built two typologies of AICCs based on doctrinal teachings and lived experiences, namely Pentecostal/Charismatic churches and mainline Protestant churches. Four of the AICCs were classified as mainline Protestant churches and five were identified as Pentecostal/Charismatic churches.

\section{Findings and Discussions}

\section{Gendering Demographic Characteristics of AICCs}

The nine AICCs in Amsterdam that participated in the research are located in the municipality of Amsterdam Southeast. Most of the members in AICCs are of Ghanaian origin. All the churches have their weekly service on Sundays, except the Seventh Day Adventist Church that meets on Saturdays. Apart from the general weekly meetings, there are sub-groups that meet during the week. The main sub-groups are women societies, men societies, youth groups, ushers, and evangelisation ministries.

Membership in the AICCs varied between 100 and 500, 40\% of which were men, and women $60 \%$ as shown in table 1 below. Five of the AICCs identified themselves as Pentecostal/Charismatic while four classified themselves as mainline Protestants. Only two of the Pentecostal/Charismatic churches had their mother churches back home while they existed as branches in the Netherlands. The other three

38 Justice, R.K.O. Kyei, Rafal Smoczynski, and Mary B. Setrana, "Evidence of Spiritual Capital in the Schooling of Second-Generation Ghanaians in Amsterdam," African Human Mobility Review 7, no.1 (2021), 90. 
Pentecostal/Charismatic churches were formed in the Netherlands and two had extended their branches to Ghana.

Table 1: AICCs in Amsterdam interviewed

\begin{tabular}{|l|c|c|l|}
\hline \multicolumn{1}{|c|}{ Name of Church } & $\begin{array}{c}\text { Date of } \\
\text { Establishment }\end{array}$ & $\begin{array}{c}\text { Population: } \\
\text { Men, } \\
\text { Women }\end{array}$ & Denomination \\
\hline Church of Pentecost & 1990 & 250,450 & Pentecostal \\
\hline $\begin{array}{l}\text { Redemption Faith } \\
\text { International Ministries }\end{array}$ & 1995 & 110,200 & Charismatic \\
\hline $\begin{array}{l}\text { Christ the King Baptist } \\
\text { Church }\end{array}$ & 1992 & 56,100 & $\begin{array}{l}\text { Mainline } \\
\text { Protestant }\end{array}$ \\
\hline $\begin{array}{l}\text { Resurrection Power } \\
\text { and Living Bread } \\
\text { Ministries }\end{array}$ & 1990 & 125,275 & Pentecostal \\
\hline $\begin{array}{l}\text { Amsterdam Seventh } \\
\text { Day Adventist Church }\end{array}$ & 1995 & 100,160 & Protestant \\
\hline $\begin{array}{l}\text { Emmanuel } \\
\text { Presbyterian Church } \\
\text { of Ghana }\end{array}$ & 2000 & 105,150 & $\begin{array}{l}\text { Mainline } \\
\text { Protestant }\end{array}$ \\
\hline $\begin{array}{l}\text { Wesley Methodist } \\
\text { Church of Ghana }\end{array}$ & 1997 & 150,250 & $\begin{array}{l}\text { Mainline } \\
\text { Protestant }\end{array}$ \\
\hline $\begin{array}{l}\text { Love Christian Centre } \\
\text { Pentecost Revival } \\
\text { Church International }\end{array}$ & 1997 & 80,50 & $\begin{array}{l}\text { Pentecostal/ } \\
\text { Charismatic }\end{array}$ \\
\hline
\end{tabular}

All the representatives of the studied AICCs emphasised that about $60 \%$ of their members were women while the remaining were men as shown in table 1 above. The ratio has been more or less the same since the inception of the studied AICCs in Amsterdam. Study after study has found that women are over-represented in churches. ${ }^{39}$ In spite of the high rate of women's presence and participation, they do not form part of the highest governing body in the hierarchical structure of these AICCs. A representative of the Redemption Faith International (RFI) narrated, "There is a three-tier hierarchical structure of the church. As at now, we do not have women in the ministerial council, but there are women in the

39 Mercy A. Oduyoye, Introducing African women's theology (Sheffield: Sheffield Academic Press, 2001), 10. 
deaconry. This is purely because of competence but not biblical as the church does not have any laws that discriminate against women." ${ }^{20}$

Androcentric hegemonic power relations are hidden in the constitution and daily practices in the exercise of religious citizenship of women and men in the religious field. Ostensibly, the constitution of most of the Pentecostal/Charismatic churches appears to be gender-neutral, but the common practice discriminates against women's representation, and consequently women's rights to leadership as religious citizens. The research discovered that competence does not explain the gender insensitivity and imbalance against women in most of the AICCs as members in the ministerial council were founding members. The puzzle persists: Why were none of the women founding members part of the ministerial council, whether to represent women's grievances and/or competences? The granting of the right of representation to women in Pentecostal/Charismatic churches even at the secondary level permits women's voices to be heard due to the gender-differentiated nature of citizenship ${ }^{41}$ as are witnessed under the subsection on agency below.

\section{Gendered Participation and Representation}

As the nation-state sets conditions for admission to citizenship, ${ }^{42}$ in much the same way, religious fields have criteria for acceptance into religious citizenship. Religious citizenship is a status that individuals have to qualify for to gain entrance. With the rite of baptism, women and men are incorporated into the religious field as religious citizens. In principle, both have the right and entitlement to participation and representation with no gender obstacles. The head pastor of the RFI related that "the church is open to all and sundry and it is mandatory that all members confirm their belongingness to the church through baptism." 43 However, data from the participant observation and informal interviews indicate that sitting arrangements in some of the AICCs were gendered, as women and men had designated or culturally accepted seating places. In most of the studied AICCs, women and men did not mingle with each other during

\footnotetext{
40 Interview: Representative of the RFI, 5 November 2015.

41 Kathleen B. Jones, "Citizenship in a Woman-Friendly Polity," Signs 15, no.4 (1990): 782.

42 Herman van Gunsteren, "Four Conceptions of Citizenship," in The Condition of Citizenship, ed. Bart van Steenbergen (London: Sage, 1994), 37.

43 Interview: Head pastor of the RFI, 16 January 2015.
} 
church services and in some church-related activities. ${ }^{44}$ Moreover, women were not supposed to sit on the altar or platform during church services, as it is only preserved for the men in the presbytery. ${ }^{45}$

The Pentecostal/Charismatic churches in this research adopted a more rigid approach to women representation compared to the mainline Protestant churches. Data from the fieldwork show that there were gender variations in the exercise of power and authority in the two typologies of the AICCs. The head pastor of the Church of Pentecost recounted, "Actually anyone can be a member of the church without discriminating against sex, race, or colour. A person is considered a full member of the church when he or she is baptised. To become an executive member of the church, one has to be part of the presbytery. The presbytery consists of deacons/deaconesses, elders, pastors, evangelists, prophets, and apostles in ascending order. The highest position within the presbytery that females can attain is deaconess. A woman cannot be ordained as a pastor. Anyway, the pastor's wife is called osofo Maame ${ }^{46}$ (Pastor Mother) although she is not a pastor. It is part of the church's teaching and the situation may change in the future, but for now women cannot rise beyond deaconship." 47

The head pastor of the Pentecost Revival church also stated: "The church is Bible believing, so anyone who wants to know Christ can be part of us irrespective of race or gender. Baptism is the rite of initiation into the church. The presbytery consists of deacons and deaconesses, elders, overseer, and pastors. There are females in the church who are deaconesses, but the church does not call females to eldership, which is the next stage after deaconship, neither can women become pastors. However, the wife of the pastor is osofo Maame. She has her role to play

44 Gender relations in contemporary Christian organisations not only include issues of leadership but also the division of lay labour during the weekly routine of church life. Women polish the brass, clean the linens, and fill the pews. Men, by contrast, have to contribute to church policy decisions, count the money, and fill the platform (Nancy Nason-Clark, "Gender Relations in Contemporary Christian Organizations," in The Sociology of Religion: A Canadian Focus, ed. Warren E. Hewitt [Toronto: Butterworths, 1993], 210).

45 Justice R.K.O. Kyei, Elizabeth N.M.K. Yalley, and Emmanuel K.E. Antwi, "Field Notes," 2014.

46 The original term is Asafo Maame (Church Mother), but all the church representatives who were interviewed, referred to it as ossfo Maame (Pastor Mother).

47 Interview: Head pastor of the Church of Pentecost, 23 October 2014. 
in the church by ensuring that women live in harmony with their families at home. ${ }^{48}$

Women within most of the studied Pentecostal/Charismatic churches are constrained from climbing the leadership ladder and fully exploring their potentials and capabilities as religious citizens due to the "masculinized ethos" that dominate church legislations and culture..$^{49}$ The religious field of the AICCs in Amsterdam is not a level playing ground whereby women and men have equal access to leadership positions. The social relationships are rather embedded in a male hegemony. Women can rise up to deaconship positions, being the least in the hierarchy of the presbytery. Citizenship is a universal yardstick against which progress can be measured, while the underlying principle of citizenship is inclusion. ${ }^{50}$ There are, however, androcentric tendencies in some Pentecostal/Charismatic churches that exclude female congregants from having equal rights to representation.

The honorary title of osofo Maame bears no ecclesial authority, but it is embedded with cultural meanings. The gender dichotomy locates the osofo Maame figure as mother and caregiver in the private sphere to take care of the children in the church and get involved in educating women in the congregation on how to nurture and maintain happy family relations. Male congregants are rather engaged in decision-making and the execution of power in the public sphere of the AICCs. It is worth noting that, in contrast with this, Charismatic churches in Ghana have osofo Maame considered as co-pastors to their husbands. ${ }^{51}$ These findings reveal the nuances and contradictions in women leadership in Charismatic churches.

A representative of Love Christian Centre reiterated: "Any baptised member could be nominated as a deacon or deaconess or elder or pastor of the church. The church hierarchy consists of the ministerial council, which is composed of the senior pastor, the associate pastor, the elders, two people from the finance department, and also a board of

\footnotetext{
48 Interview: Head pastor of Pentecost Revival, 15 August 2014.

49 Jennifer L. Lawless and Richard L. Fox, It Takes a Candidate: Why Women Don't Run for Office (New York: Cambridge University Press, 2005), 10.

50 Marshall, Citizenship and Social Class and Other Essays, 29.

51 Soothill, Gender Social Change and Spiritual Power, 29.
} 
trustees. Besides that, we have the deaconry which consists of deacons and deaconesses and then we have the workers." 52

From the data, our analysis is that women are considered as "secondclass" citizens in this space. ${ }^{53}$ Women's ability to represent is discounted because of stereotypes that are perpetuated by sexism, which associate power and leadership with men, while women are excluded from leadership roles. The understanding is that the result of spiritual and religious values, culturally grounded in Pentecostal/Charismatic teachings, are generating a biased power relation between women and men in the religious field. Social boundaries are constructed and sustained by a male hegemony that governs the exercise of equal rights by religious citizens in most AICCs. The social boundaries are laden with power relations and gender inequalities. ${ }^{54}$ Some of the Pentecostal/Charismatic churches echo their doctrinal teachings from subjective biblical interpretations that exclude women from the hierarchical structure.

The mainline Protestant churches have created spaces for women to be part of their leadership, however, with more constraints for women compared to men. A founding member of the Amsterdam branch of the Presbyterian Church of Ghana communicated the following: "The church has membership in Ghana and different parts of the world. Anyone can be admitted as a member of the church, but a person is fully recognised as a member of the church when he or she is in communion with the church through baptism and participate in the sharing of bread and wine in the church. The church does not place any gender limit to the attainment of leadership positions. The church has a lot of pastors who are women and some of them hold key positions. The caretaker of our branch is a woman, and we have a woman ordained minister in one of our branches here in Holland. The church executive council has equal representation of both men and women." 55

A founding member of the Amsterdam branch of the Methodist Church of Ghana also stated: "The church does not discriminate against any group

\footnotetext{
52 Interview: Representative of Love Christian Centre, 7 September 2014.

53 Ruth Lister, Citizenship: Feminist Perspectives (New York: New York University Press, 2003), 69.

54 Paul Boyle, "Population Geography: Transnational Women on the Move," Progress in Human Geography 26, no.4 (2002): 537.

55 Interview: Founding member of the Amsterdam branch of the Presbyterian Church of Ghana, 25 September 2014.
} 
of people, sex, or race from joining the church. Membership is obtained in the church through infant or adult baptism and partaking in the celebration of the Last Supper. Women are ordained as pastors in the Methodist church of Ghana without any hindrance to gender differences. Some of the ordained women ministers have risen to different leading positions in the church. The first secretary general of the Amsterdam branch was a woman. My wife was the circuit leader when she was in Ghana. Here in Holland, she led the newly formed Methodist Church of Ghana in The Hague."56

These mainline Protestant churches are regendering citizenship in the religious field by reviewing their constitution and daily practices towards the representation of both women and men in the churches' hierarchical structures. The regendering of citizenship empowers some women in the public sphere and corrects the gender imbalances in women's representation in the religious field of some of the studied AICCs. ${ }^{57}$ Whereas most of the mainline Protestant churches in our study have taken up practical steps to bridge the gender gap in woman representation, almost all the Pentecostal/Charismatic churches are entrenched in gender dichotomy that deter women from equal rights to representation in leadership. Data from the fieldwork further show that none of the Pentecostal/Charismatic churches and the mainline Protestant churches in this study has recruited a woman pastor to head their congregation.

\section{Agency Mitigates Gendered Leadership Practices}

In cognisance of the structural and institutional gendered constraints in the access to participation and representation in the religious field, some women in this research indicated that they "regendered citizenship." The process of regendering citizenship embraces individual members' rights to participation, which is translated in the exercise of personal agency by some of the respondents in the public sphere of the AICCs. Some of the women respondents acted and reacted to the gendered constraints posed by the church structures, which were imbued with some biblical teachings that hindered their attainment of some degree of religious citizenship. A participant narrated about the agency of women compared to men in the youth group of her church: "Women are more serious and active than men in the youth group. For example, if we organise youth

\footnotetext{
56 Interview: Founding member of the Amsterdam branch of the Methodist Church of Ghana, 6 November 2014.

57 Lister, Citizenship, 69.
} 
programmes in the church and we ask people to spontaneously take up duties, the women are always proactive and respond positively, whereas the men are reluctant and are normally obliged before they get involved. The men always want to play the supporting role while the women assume the leading roles. We, the women in the youth group know what we want, and we work towards our goals without any intimidation. We believe in equal power relations between men and women as it is translated in our daily lives in the Dutch society." 58

Another interviewee also narrated the exercise of agency in her church together with a friend: "A woman friend and I took up the initiative to mobilise the young girls and boys in the church. The aim was to engage them with Bible teachings and other practical daily tips, which they may be lacking in their participation in the main church service. We presented our proposal to the church council and it was approved and the project was successful. As we were brought up in the Netherlands, we have embraced the right to equal access to leadership and participation, which empowers us to live it out in the church." 59

Agency as self-definition occurs within a social setting through the awareness of one's self and one's self-conception as socially founded. ${ }^{60}$ In spite of the androcentric religious citizenship practices within the studied AICCs, some women do express leadership qualities and abilities in the day-to-day activities of their churches. Some of the women respondents created their own social space within the religious field where they exhibited leadership. Agency is a relational process ${ }^{61}$ that enables women to resist the dominant androcentric norms that deter them from competing and engaging in the exercise of leadership in the religious field. Participatory citizenship or the practice of citizenship is in a constant process of mutation and negotiation. Representation is negotiated and redefined in the religious field of some AICCs in Amsterdam through lived experiences.

\footnotetext{
58 Interview: Participant 1 in church, 6 January 2015.

59 Interview: Participant 2 in church, 23 December 2017.

60 Kathryn Abrams, "From Autonomy to Agency: Feminist Perspectives on Self-Direction," William \& Mary Law Review 40 (1999), 825.

61 Catharine Mackinnon, Towards a Feminist Theory of the State (Cambridge, MA: Harvard University Press, 1989), 91-2.
} 


\section{Conclusions}

Theoretically, this article has contributed to the advancement of the understanding in the contested concept of religious citizenship from a gendered perspective, as it demonstrates that citizenship is not applied only to the nation-state but also to meso level associations. Empirically, the study has shown the gendered nature of leadership within the religious field in the participation and representation of religious citizens in the AICCs in Amsterdam. The conceptualisation of religious citizenship permitted the discussion of the gendered distribution of rights of membership, opportunities, and leadership positions within the AICCs in Amsterdam. Religious citizenship has revealed the multi-layered and multiplicity of power relations that exist in these AICCs.

The study concludes that the practice of religious citizenship is gendered in complex and diverse ways. Pentecostal/Charismatic churches in this study are entrenched in the gender dichotomy as women congregants are deprived access to priesthood and some leadership positions, compared to mainline Protestant churches that allow women to compete for all hierarchical positions. When this finding is juxtaposed with the work of Soothill, ${ }^{62}$ it reveals the nuances and contradictions in the lived experiences of woman leadership in Charismatic churches, in spite of the gendered challenges. The study found, however, that none of the mainline Protestant churches in this study has recruited women as head pastors.

The study also noted that some women are situated in de facto secondclass citizenship positions in the religious field, ${ }^{63}$ which undermines women's search for equal rights as religious citizens. The gendered nature of religious citizenship is not peculiar to the studied AICCs in Amsterdam, as it reflects similarly in Pentecostal churches in Ghana that subjectively interpret the Bible as legitimising gender discrimination, so as to perpetuate the marginalisation of women in official leadership positions. The reverse is, however, the case with mainline Protestant churches who are adopting an inclusive approach in the recruitment of leaders. Mainstreaming gender in AICCs require the transformation of

\footnotetext{
62 Soothill, Gender Social Change and Spiritual Power.

63 Kia L. Caldwell, Kathleen Coll, Tracy Fisher, Renya K. Ramirez, and Lok Siu, "Introduction Collectivity and Comparativity: A Feminist Approach to Citizenship," in Gendered Citizenships, eds. Kia L. Caldwell, Renya K. Ramirez, Kathleen Coll, Tracy Fisher, and Lok Siu (New York: Palgrave Macmillan, 2009), 4.
} 
the patriarchal reading of the holy Scriptures that have become the yardstick for violating the humanity of women. ${ }^{64}$

True citizenship blossoms where there is sharing in solidarity. ${ }^{65}$ The discussion demonstrated the persistence of women subordination in the religious field in spite of the numerical strength of women and their effective roles. The motherly qualities referred to as osofo Maame or caregivers represent skills, values, and competence that need to be fused into the leadership of most of the studied AICCs to enhance their mission and goals. These skills are peculiar to women and make women representation unique and different from men's representation. The exclusion of women from the highest decision-making body of most AICCs in Amsterdam does not permit the taking of decisions that truly reflect the concerns of women in the religious field. The research revealed the hardships and daily struggles of women in AICCs, living at the intersection of African, woman, and Christian identities.

The research pointed out that the relation between the institutional position of participation and representation and the practice of religious citizenship are not straightforward, as some women navigate their ways around women subordination and androcentric practices. Women are not passive in their lived experience in the AICCs, as they contest, reinterpret, and position themselves as active actors. The self-recognition of the structural constraints of the AICCs empowers some women to negotiate leadership positions, even if informally.

\section{References}

Abrams, Kathryn. "From Autonomy to Agency: Feminist Perspectives on Self-Direction." William \& Mary Law Review 40 (1999): 805-46.

Adams, Carole E. Women Clerks in Wilhelmine Germany: Issues of class and gender. Cambridge: Cambridge University Press, 2002.

Adasi, Grace S. and Dorothy A. Frempong. "Multiple roles of African women leaders and their challenges: The case of the Presbyterian Church of Ghana." Research on Humanities and Social Sciences 4, no.11 (2014): 63-8.

\footnotetext{
64 Oduyoye, Gender and Theology in Africa Today, 7.

65 Oduyoye, Introducing African women's theology, 25.
} 
Asamoah-Gyadu, Kwabena J. "Mediating spiritual power: African Christianity, transnationalism and the media." In Religion crossing boundaries: Transnational religious and social dynamics in Africa and the new African Diaspora, edited by Afe Adogame and James V. Spickard, 87-103. Leiden: Brill, 2010.

Aymer, Paula. "West African and Caribbean women evangelists." In Spirit on the Move: Black Women and Pentecostalism in Africa and the Diaspora, edited by Judith Casselberry and Elizabeth A. Pritchard, 109-27. Durham: Duke University Press, 2019.

Baffoe, Michael. "Spiritual Well-being and Fulfilment, or Exploitation by a Few Smart Ones? The Proliferation of Christian Churches in West African Immigrant Communities in Canada." Mediterranean Journal of Social Sciences 4 (2013): 305-16.

Barbalet, Jack M. Citizenship: Rights, Struggle, and Class Inequality. New York: Taylor \& Francis Group, 1988.

Bourdieu, Pierre and Loïc J.D. Wacquant. An Invitation to Reflexive Sociology. Chicago: University of Chicago Press, 1992.

Boyle, Paul. "Population Geography: Transnational Women on the Move." Progress in Human Geography 26, no.4 (2002): 531-43.

Bubeck, Diemut E. Care, Gender and Justice. Oxford: Clarendon Press, 1995.

Caldwell, Kia L., Kathleen Coll, Tracy Fisher, Renya K. Ramirez, and Lok Siu. "Introduction Collectivity and Comparativity: A Feminist Approach to Citizenship." In Gendered Citizenships, edited by Kia L. Caldwell, Renya K. Ramirez, Kathleen Coll, Tracy Fisher, and Lok Siu, 1-15. New York: Palgrave Macmillan, 2009.

Choenni, Chandersen E.S. Ghanazen in Nederland: Een Profiel. Den Haag: Ministerie van Binnenlandse Zaken en Koninkrijkszaken, 2002.

Connell, Robert W. Masculinities. Berkeley: University of California Press, 1995. 
Davis, Kathy, Mary Evans, and Judith Lorber (eds.). Handbook of Gender and Women's Studies. London: Sage, 2006.

Finke, Roger and Rodney Stark. The Churching of America 1776-1990: Winners and Losers in Our Religious Economy. New Brunswick: Rutgers University Press, 1992.

Frymer-Kensky, Tikva. Studies in Bible and Feminist Criticism.

Philadelphia: Jewish Publication Society, 2006.

Gemeente Amsterdam. Amsterdam in Cifers 2013. Gemeente Amsterdam, Amsterdam: O+S Research.

http://www.ois.amsterdam.nl/media/Amsterdam\%20in\%20cijfers\% 202013/HTML/\#/62/ (Accessed 20 March 2019).

Hadebe, Nantondo. Gender, Gender Equality, and the Church: Institute for Contextual Theology. Durban: Institute for Contextual Theology, 2017.

Hobson, Barbara and Ruth Lister. "Citizenship." In Contested Concepts in Gender and Social Politics, edited by Barbara Hobson, Jane Lewis, and Birte Siim, 23-53. Aldershut: Edward Elgar Publishing, 2002.

Imperatori-Lee, Natalia. "Women Priests or Not, Gendered Theology is Hurting the Church." America: The Jesuit Review, 6 November 2016. https://www.americamagazine.org/faith/2016/11/06/womenpriests-or-not-gendered-theology-hurting-church (Accessed 12 July 2021).

Interview: Founding member of the Amsterdam branch of the Methodist Church of Ghana, 6 November 2014.

Interview: Founding member of the Amsterdam branch of the Presbyterian Church of Ghana, 25 September 2014.

Interview: Head pastor of Pentecost Revival, 15 August 2014.

Interview: Head pastor of the Church of Pentecost, 23 October 2014.

Interview: Head pastor of the RFI, 16 January 2015. 
Interview: Participant 1 in church, 6 January 2015.

Interview: Participant 2 in church, 23 December 2017.

Interview: Representative of Love Christian Centre, 7 September 2014.

Interview: Representative of the RFI, 5 November 2015.

Jepperson, Ronald. "Institutions, Institutional Effects, and Institutionalism." In The New Institutionalism in Organizational Analysis, edited by Walter W. Powell and Paul J. DiMaggio, 14363. Chicago: University of Chicago Press, 1991.

Jones, Kathleen B. "Citizenship in a Woman-Friendly Polity." Signs 15, no.4 (1990): 781-812.

Kapinde, Stephen A. and Eleanor T. Higgs. "Global Anglican Discourse and Women's Ordination in Kenya: The Controversy in Kirinyaga, 1979-1992, and its Legacy." Journal of Anglican Studies (2021): 118.

Knipscheer, Jeroen W., Eleonore de Jong, Rolf Kleber, and Ekow Lamptey. "Ghanaian migrants in the Netherlands: General health, acculturative stress and utilization of mental health care." Journal of Community Psychology 28, no.4 (2000): 459-76.

Kyei, Justice R.K.O., Elizabeth N.M.K. Yalley, and Emmanuel E.K. Antwi. Field Notes. 2014.

Kyei, Justice R.K.O. and Rafal Smocynski. "Building Bridges or Bonds: The Case of Ghanaian Second Generation Migrants in Ghanaian Churches in Amsterdam." Romanian Journal Anthropological Research and Studies 6 (2016):13-24. http://www.journalstudiesanthropology.ro/en/no-6-2016/r46/.

Kyei, Justice R.K.O. and Rafal Smocynski. "Religious citizenship and gendered sanctions in the lived experience of second generation Ghanaians." Social Compass, 66, no.4 (2019): 505-21. $10.1177 / 0037768619868419$. 
Kyei, Justice R.K.O, Rafal Smoczynski, and Mary B. Setrana. "Evidence of Spiritual Capital in the Schooling of Second-Generation Ghanaians in Amsterdam." African Human Mobility Review 7, no.1 (2021): 89-107.

Lawless, Jennifer L. and Richard L. Fox. It Takes a Candidate: Why Women Don't Run for Office. New York: Cambridge University Press, 2005.

Lister, Ruth. "Citizenship and Gender." In Blackwell Companion to Political Sociology, edited by Kate Nash and Alan Scott, 323-31. Oxford: Blackwell Publishing, 1997.

Lister, Ruth. "Citizenship: Towards a feminist synthesis." Feminist Review 57, no.1 (1997): 28-48.

Lister, Ruth. Citizenship: Feminist Perspectives. New York: New York University Press, 2003.

Mackinnon, Catharine. Towards a Feminist Theory of the State. Cambridge, MA: Harvard University Press, 1989.

Marshall, Thomas H. Citizenship and Social Class and Other Essays. Cambridge: Cambridge University Press, 1950.

Mensah, Joseph. "'Doing religion' overseas: The characteristics and functions of Ghanaian immigrant Churches in Toronto, Canada." Societies Without Borders 4 (2009): 21-44.

Nason-Clark, Nancy. "Gender Relations in Contemporary Christian Organizations." In The Sociology of Religion: A Canadian Focus, edited by Warren E. Hewitt, 215-32. Toronto: Butterworths, 1993.

Ndeda, Milfred A.J. "The Nomiya Luo Church: A gender analysis of the dynamics of an African Independent Church among the Luo of Siaya District." In Gender, Literature and Religion in Africa, edited by Elizabeth le Roux, Mildred A.J. Ndeda, George Nyamndi, F.E.M.K. Senkoro, and Isaac Ssetuba, 49-78. Dakar: Council for the Development of Social Science Research in Africa, 2005. 
Oduyoye, Mercy A. Introducing African women's theology. Sheffield: Sheffield Academic Press, 2001.

Oduyoye, Mercy A., Gender and Theology in Africa Today. Accra: Institute of Women in Religion \& Culture Accra, Ghana, 2006.

Oduyoye, Mercy A. and Kanyoro R.A. Musimbi (eds.), The Will to Arise: Women, Tradition, and the Church in Africa. Maryknoll: Orbis Books, 1992.

Prins, Baukje. "Mothers and Muslima's, Sisters and Sojourners: The Contested Boundaries of Feminist Citizenship." In Handbook of Gender and Women's Studies, edited by Kathy Davis, Mary Evans, and Judith Lorber, 234-50. London: Sage, 2006.

Ralston, Helen. "Citizenship, identity, agency and resistance among Canadian and Australian women of South Asia." In Women, Migration and Citizenship: Making Local, National and Transnational Connections, edited by Evangelia Tastsoglou and Alexandra Dobrowolsky, 183-200. Aldershot: Ashgate Press, 2006.

Sewell, William H. Jr. "A theory of structure: Duality, agency, and transformation." American Journal of Sociology 98, no.1 (1992): 129.

Soothill, Jane E. Gender Social Change and Spiritual Power: Charismatic Christianity in Ghana. London: Brill. 2007.

Soothill, Jane E. "Gender and Pentecostalism in Africa." In Pentecostalism in Africa, edited by Andrew Davies and William Kay, 191-219. London: Brill, 2015.

Stark, Rodney and William S. Bainbridge. The Future of Religion: Secularization, Revival, and Cult Formation. Berkeley: University of California Press, 1985.

Statistics Netherlands. "Population: Sex, age, migration background and generation," 1 January 2019.

https://opendata.cbs.nl/\#/CBS/en/dataset/37325eng/table (Accessed 1 May 2020). 
Tastsoglou, Evangelia and Alexandra Dobrowolsky (eds.). Women, Migration, and Citizenship: Making Local, National, and Transnational Connections. Vol. 8. Hampshire: Ashgate Publishing, 2006.

Taylor, Charles. "The politics of recognition." In Multiculturalism:

Examining the Politics of Recognition, edited by Amy Gutmann, 12-34. Princeton, NJ: Princeton University Press, 1994.

Ter Haar, Gerrie. "Strangers in the Promised Land: African Christians in Europe." Exchange 24, no.1 (1995): 1-33.

Ter Haar, Gerrie. "The African Diaspora in the Netherlands." In New Trends and Developments in African Religions, edited by Peter B. Clarke, 245-62. Westport: Greenwood Press, 1998.

Turner, Bryan S. "Outline of a theory of citizenship." Sociology 24, no.2 (1990): 189-217.

Van den Bos, Dick. "Kerken in de Bijlmer zijn parels in AmsterdamZuidoost." Reformatorish Dagblad, 27 June 2013.

http://www.refdag.nl/kerkplein/kerknieuws/kerken_in_de_bijlmer_zi jn_parels_in_amsterdam_zuidoost_1_749924 (Accessed 1 May 2020).

Van Gunsteren, Herman. "Four Conceptions of Citizenship." In The Condition of Citizenship, edited by Bart van Steenbergen, 36-48. London: Sage, 1994.

Wharton, S. Army. The Sociology of Gender: An Introduction to Theory and Research. Oxford: Blackwell Publishing, 2005. 